\title{
THE
}

\section{Social Class Myopia: The Case of Psychology and Labor Unions}

Bernice Lott

University of Rhode Island, blott@uri.edu

Follow this and additional works at: https://digitalcommons.uri.edu/psy_facpubs

The University of Rhode Island Faculty have made this article openly available.

Please let us know how Open Access to this research benefits you.

This is a pre-publication author manuscript of the final, published article.

Terms of Use

This article is made available under the terms and conditions applicable towards Open Access

Policy Articles, as set forth in our Terms of Use.

\section{Citation/Publisher Attribution}

Lott, B. (2014). Social Class of Myopia: The Case of Psychology and Labor Unions. Analysis of Social Issues and Public Issues, 14(1), 261-280. doi: 10.1111/asap.12029

Available at: https://doi.org/10.1111/asap.12029 
Running head: PSYCHOLOGY AND LABOR UNIONS

Social Class Myopia: The Case of Psychology and Labor Unions

Bernice Lott

University of Rhode Island

\begin{abstract}
Author Note
Correspondence should be addressed to: Bernice Lott, Ph.D., Psychology Department, Chafee Building, University of Rhode Island, Kingston, Rhode Island, 02881 (email) blott@uri.edu, (FAX) 401-874-2157
\end{abstract}




\begin{abstract}
This paper explores the potential for psychology's research agenda likely to follow from new scholarship on working class issues and organized labor. Such an agenda fits well with the official mission of APA - to advance knowledge that benefits society and improves people's lives. I focus on our paucity of interest in the institution that gives the American working class a voice - the labor union. We know that work is one of the central focuses in the lives of most people and that the work experience is deeply implicated in satisfaction with life. The efforts of organized labor to achieve economic fairness and justice, and a healthy workplace environment, are intertwined with multiple corollary consequences that constititue a wide and complex spectrum - from physical job safety and economic security on one end, to the psychological benefits of heightened self-esteem, respect, dignity, empowerment and affiliation on the other - all related to satisfaction with life.

Keywords: labor unions, working class issues, APA mission
\end{abstract}


Social Class Myopia: The Case of Psychology and Labor Unions

The official mission of the American Psychological Association is "to advance the creation, communication and application of psychological knowledge to benefit society and improve people's lives," and among its five "Core Values" are "Social justice, diversity, and inclusion" (APA, nd). These laudable objectives engender pride in our organization and discipline. Yet, research and applications in U. S. psychology have been focused primarily on human beings who, while slowly acknowledged to differ in gender, ethnicity and sexuality, continue to be observed with little recogniton of social class. As noted by J. C. Williams (2012, p. 39), "Americans display a convenient tone deafness when it comes to class." And so does American psychology.

Ironically, the assumption of classlessness is contradicted by our own data on such individual difference measures as education, income, occupation, and access to resources associated with health and welfare. Acknowledgment of the significance of these indices for people's lives, families, and communities can be found in our literature (see Lott, 2010, 2012; Lott \& Bullock, 2001), but understanding and studying them under the construct of "social class" remains problematic and difficult for our discipline.

Psychology's historically narrow view of diversity can be illustrated in many areas of theory, research, and practice. Here, my focus is specifically on the paucity of interest in, and neglect of, the American labor union - despite its continuously active engagement in efforts to directly and indirectly benefit society and improve people's lives. These efforts, while centered on the achievement of economic benefits and a fair and healthy workplace environment, are deeply intertwined with multiple corollary positive 
consequences. The achievements of organized labor constitute a wide and complex spectrum, from physical job safety and economic security on one end, to the psychological benefits of heightened self-esteem, respect, and affiliation, on the other. As concluded succinctly by Pacek (2009, p.240), "organized labor exerts a largely positive effect on human well-being."

Given the fact that workers spend more of their waking hours engaged in work than in any other activity, and that work is one of the central focuses of the lives of most people (Coshow \& Radcliff, 2009), it is difficult to explain the lack of attention given by psychology to efforts by unions to improve and strengthen the workplace. As clearly noted by Dutt and Radcliff (2009, p. 15): "the work experience affects not only one's economic well-being, but one's sense of dignity and self-respect" and "the labor union, as the advocate and agent of the worker in obtaining both income and dignity, has an obvious potential for affecting an individual's satisfaction with life." The union is the one and only formal and institutional advocate for workers.

\section{Ignoring the Role of Unions}

Psychlogy is not alone In ignoring the role played by the labor movement in the lives of American workers. Such omission may be found in the U. S. media which not only do not usually present fair and extensive discussions of class (Heider, 2004) but are also particularly negative in their treatment of working-class and labor issues. Despite the fact that skilled and unskilled workers constitute about half of the labor force in the U.S., it is the so-called middle class that predominates in television images, stories, news, and entertainment. Martin (2004, p. 11) notes that "Perhaps the most important characteristic 
of mainstream coverage of labor is that the media are often not covering labor at all." In 2002, there were fewer than five "labor beat" reporters left at U.S. daily newspapers. When unions are presented, they are most often described as not negotiating in good faith, with workers who are greedy and self-destructive, and not interested in the larger public's well-being (Heider, 2004; Martin, 2004). A study of $20^{\text {th }}$ century films by Bodner (2003) found that, while the Hollywood screen portrayed a variety of working-class characters, it "almost never celebrated the labor radical or the power of the militant union" (p. 89). And Coshow and Radcliff (2009, p. 294) write about the "political ambivalence afforded labor movements" that is reflected in their "academic treatment within the social sciences."

There are many examples of scholarship in our discipline that is incomplete lacking in full attention to relevant issues - by virtue of neglecting to even mention organized labor. Illustrative is an issue of the American Psychologist that included several papers on retirement. Shultz and Wang (2011), as well as Adams and Rau (2011), discuss the role of Social Security and employer pensions in making retirement possible for vast numbers of Americans. They also call attention to changes in employment, such as downsizing and reduced pension and medical benefits, that negatively influence plans for retirement. Yet, there is no discussion of the historical and current relationship between employee benefits and labor union influence and membership. Wang, Henkins, and van Solenge (2011, p. 209) note that "predictors of retirement adjustment quality....are directly associated with different types of resources that retirees have" - again, there is no mention of unions. Similarly, a four-day 
conference co-sponsored by APA on work, stress, and health, as described and summarized (Dingfelder, 2011), seems not to have included the role of organized labor as a topic for discussion.

Dobson and Schnall (2009) note the significant disconnect between our knowledge of the influence of working conditions on mental health and our lack of attention to organized efforts to improve these conditions. For example, in a book on multidisciplinary perspectives of sex discrimination in the workplace (Crosby, Stockdale \& Ropp, 2007), the index does not include any references to either labor unions or collective bargaining, ignoring research on sexual harassment, for example, in which union members have served as respondents (cf. Bulger, 2001). An APA volume on psychology's contributions to a healthy world (Rozensky, Johnson, Goodheart, \& Hammond, 2004) includes three chapters on the importance of the workplace, but there is no mention of organized labor. Even a non-mainstream association like Psychologists for Social Responsibility (2011) overlooked labor unions in an otherwise inclusive presentation of an action agenda for the promotion of psychological health and well-being.

One might expect that organzed labor would be a prominent topic within the field of industrial-organizational (I-O) psychology, but that is not the case. According to Zickar (2004), I-O psychology has ignored unions, despite the stated mission of the Society for Industrial-Organizational Psychology "to "promote human welfare through the various applications of psychology to all types of organizations"' (p. 146). He points out that, in the 1990s, labor unions were mentioned in the title or abstract of only $1.3 \%$ of 
published articles in the top ten most I-O relevant and prestigious journals, and only 4 of 3468 SIOP members in 2003 identified union issues as an area of interest.

I-O psychology continues to be closely identified with the issues and concerns of management, as the work in relevant journals and books illustrates. Zickar (2004) argues that this focus has been clearly evident since shortly after passage of the 1935 National Labor Relations Act which sought to curtail many of the overt strategies that companies had used to fight efforts to unionize. Companies began to recruit applied psychologists to use personality tests to screen out likely union members among job applicants who showed signs of "neurotic tendencies," and to administer attitude and morale surveys to existing employees to identify workplaces that might be susceptible to a unionization campaign. Most of industrial psychology has focused on industrial efficiency, and sizable numbers of industrial psychologists are hired by private industry to conduct research reflecting the interests of business and management (Zickar, 2003).

Ross Stagner and Arthur Kornhauser were early exceptions in recognizing the positive values of unions, with Kornhauser emphasizing the well-being of workers and potential relationships between workplace conditions and mental health (Vinchur \& Koppes, 2011). Another early positive approach to labor unions is represented by a SPSSI committee on "Trade Union Affiliation" and a vote by the SPSSI membership at its Septemer 1938 meeting in favor of unionization for its members (Finison, 1986). This concern, however, quietly faded away in the 1940s when SPSSI became increasingly involved with the war and national morale as well as debates over "the proper relation between science and social action" (p. 28). 
Avoidance of - or hostility to - labor unions within I-O psychology and an overwhelming focus on management issues is well illustrated in the three volume $(2,300$ page) handbook of industrial psychology recently published by APA (Zedeck, 2011). The index has one footnote and two single page mentions of labor unions (and no mention of social class). The handbook contains descriptions of research that may well have profited from the inclusion of union issues and membership. For example, Griffin and Clarke (2011) studied ways to reduce stress at work and increase well being, but they considerred only organizational interventions - e.g., management sponsored health promotion programs and stress counseling. The authors explicity reject changes in "the work environment", pay increases or benefits, as "not always...practicable or desirable." In another example, Hammmer and Zimmerman (2011) write about quality of work life and discuss many work-family topics and public policies. There is no mention of labor unions. Similarly, Greenberg (2011) explores the important subject of fairness in the workplace. Discussed are perceptions of justice, different kinds of justice, and how to measure organizational justice. We can perhaps guess at the author's attitudes toward unions when we read the following: "negative reactions of employees who believe they have been victims of injustice" can be illustrated by "the ubiquitous image of placards proclaiming 'unfair' hoisted in the air by disgruntled strikers on picket lines" (p. 271). While noting that labor unrest is likely to stem from feelings of injustice by workers and that "perceptions of injustice...take a toll on employees' physical and mental well-being" (p. 312), the author never mentions the potential positive role of organized labor. 


\section{A Very Brief Look at U.S. Labor History}

In the 1860 s, following the abolition of slavery, workers in the U.S. began to organize for an eight-hour work-day to allow more time to be with their families, for education, self-improvement, and for leisure. "Agitating for shorter hours became a broad-based mass movement" (Remes, 2012) which was greeted by employers in power (aided in some cases by state militias) with broken promises, police harassment and beatings, raids, strike-breaking, lock-outs, and execution of labor leaders convicted of being anarchists.

In 1884, President Grover Cleveland declared the first Monday in September to be Labor Day, and a national holiday; shortly afterward he sent 12,000 troops to break up the Pullman Strike (Flanders, 2012). The mid-1880s saw the rise of the American Federation of Labor (AFL), which led the labor movement until the 1930s when the Congress of Industrial Organizations (CIO) was formed. Skilled workers had found a home in the AFL, but immigrant workers who were largely unskilled had turned to the Industrial Workers of the World (IWW), which had a radical vision of class struggle. The famous Lawrence Textile Strike of 1912 (the "Bread and Roses" strike) was led by the IWW. This was called "the strike for three loaves:" because the weekly pay decrease of 32 cents, that set off the strike, bought that much bread in 1912. After nine bitter weeks, the mill owners gave in to the demands of the strikers for wage increases, bonus pay, and amnesty for the strikers - agreements on which they later reneged (Bread \& Roses Centennial, 2012). 
It was not until passage of the Fair Labor Standards Act in 1938 that the eighthour day became a matter of federal law. Both the eight-hour day and the 40-hour work week are the result of union initiatives and struggles for fair rewards for labor; and the belief in a social contract of reciprocity between employer and worker. The laws that were proposed and finally enacted were meant "to allow for physical and mental recovery time from work" (Dobson \& Schnall, 2009, p. 113). According to some analysts (e.g., Kahlenberg \& Marvit, 2012), it was organized labor that helped build a sturdy middle-class in the U.S. after World War II and was instrumental in achieving the positive reception later given to such progressive federal legislation as Medicare and the Civil Rights Act. New Deal legislation gave workers a legal right to choose union membership, thus puttiing the power of the federal government on the side of labor. New laws dealt with unemployment compensation, overtime pay, the minimum wage, and Social Security. The National Industrial Recovery Act (the Wagner Act) of 1933 "required industries to work with the federal government to set up maximum working hours, minimum wages standards, and fair practice codes. Employees were given the right to organize and bargain collectively, free from employer restraints or coercion (Brennen, 2004, p. 234).

During the 1930 s over 4 million workers joined unions. Nearly 30 percent of U.S. workers belonged to unions in 1945, and $35 \%$ in the mid-1950s. During the first 30 years after World War II, the labor union voice was a strong one in contract negotiations, in raising wages and working standards for all workers, both union and non-union (Feeney, 2012). In the two and a half decades following the end of World 
War II, living standards were raised for U.S. workers through collective bargaining by strong unions (Zweig, 2004).

By 1983 , however, only 20.1 percent of workers were in unions. The downswing began in the 70 s and 80 s when unions were reluctant to use the powerful weapon of the strike and were faced with strong corporate offensives (Greenhouse, 2008). According to Martin (2004, p. 32), "labor's postwar decline" in membership and economic and political power can be attributed to the "overlapping factors of unfavorable legislation, employer resistance, labor's own growing conservatism, and changes in popular attitudes." Now, in the second decade of the $21^{\text {st }}$ century, union membership is at its lowest point ever - 11.9\% in 2011 (Loomis, 2011; Milkman, 2007). This negative change contrasts with union growth in such disparate countries as Germany, Canada, and Korea (Collins, 2011).

Along with the dramatic numerical change in union membership has been the sharp change in its social class composition. Union membership has declined among the poorest third of the income distribution, while it has increased among the top twothirds (Leighley \& Nagler, 2007). In a historical reversal, unionists in the public sector now outnumber those in the private sector, are more than half of all unionized workers (Lichtenstein, 2012), and 37 percent of all government workers (Chen, 2010). Union membership is greatest In the Northeast, West Coast, and Upper Midwest, and least in the South and Southwest (Maisano, 2011).

Some new initiatives appear to be revitalizing the labor movement. Living-wage campaigns, for example, that began in 1994, have spread, succeeding in raising wages 
and helping to maintain union jobs in cities and states that have adopted living-wage ordinances (Luce, 2005). Some local rank-and-file actions have also been successful, e.g., warehouse employee strikes at Wal-Mart, protests by seafood processing workers and other food-industry plants. Direct action by warehouse and food workers have won benefits (Chen, 2012).

\section{Anti-Union Tactics and Consequences}

"[O]rchestrated resistance to union formation and collective bargaining...is part of [our]...country's history" (Zandy, 2004, p. 43). From the beginning, union growth was fought by industrialists through intimidation and harassment of organizers, and the use of violence. During the infamous Palmer Raids, on January 1, 1920, 10,000 active union workers were arrested and over 400 were deported (Zweig, 2004). This was followed by restrictive laws to make organizing and union membership more and more difficult (Collins, 2011; Martin, 2004). Especially damaging to unions were two laws passed after World War II. The Taft-Hartley Act of 1947 outlawed such union tactics as slow-downs, wildcat strikes, and sit-downs. Union officers were required to sign AntiCommunist loyalty oaths; and state laws to ban "union shops" were permitted. TaftHartley was followed in 1959 by the Landrum-Griffin Act that limited the right to picket during strikes, and required unions to open their records to federal investigators.

Unions, especially those in the public sector, are currently targeted for blame for state budget deficits and fiscal problems, said to result from pensions and benefits and overpaid city and state workers (e.g.,Cooke, 2011b; Greenhouse, 2011b; Moberg, 2011). Anti-union legislation was recently passed by several Republican controlled 
legislatures, and particularly singled out are unions representing teachers, municipal workers, police and firefighters. As noted by Greenhouse (2012b): "In community after community...teachers' unions have faced a push for concessions, whether to scrap tenure protections or to rely heavily on student test results to determine who gets a raise and who gets fired" (par. 2). In the film "Won’t Back Down", a film critic for the New York Times noted that teachers' union leaders are portrayed as cynical and self-serving; one teacher as "a lazy, tenured lump of pedagogical indifference"; and another teacher (one of the two film heroines) as a "once-proud teacher whose idealism and dedication have withered after years of frustration" (Scott, 2012).

Current employer tactics in the private sector include the "lock-out" of unionized workers and the hiring of replacements. This tactic was employed by the American Crystal Sugar company of Minnesota, whose CEO compared the union to a cancerous tumor that had to be removed (Diamond, 2011). Greenhouse (2008) has written in great detail about "the many economic and social forces....arrayed against the American worker" (p. 13), about the tactics that corporations have been employing in their fight against union organizing, and their efforts to weaken the labor movement. Workers fear asking for raises, protesting poor working conditions, the pink-slips of layoffs, and retaliation when they are involved in pro-union activities. A lucrative "union-avoidance industry" of 2,000 consultants ranges from "shady outfits...to some of the nation's most reputable law firms" (Greenhouse, 2008, p. 249). Two federal commission studies have documented the use of such consultants, reported to have been hired by 75 percent of companies. Recommended by the consultants are tactics such as forcing employees to 
attend anti-union propaganda meetings; requiring workers to attend one-on-one meetings to hear anti-union messages from managers; and threatening to close companies if unions win an election (cf. Greenhouse, 2008).

So-called Right to Work legislation, currently law in 22 states, makes it illegal for labor contracts to require workers to pay union dues. Workers in Right to Work states earn less and are less likely to receive employer-sponsored health care (King, 2011); in 2012, six such states were among the ten in the nation with the highest rates of unemployment (Rosenthal, 2012). While it is illegal to fire someone for trying to organize a union, companies do this repeatedly since the penalties are poorly enforced and weak - back pay for the fired employee (Kahlenberg \& Marvit, 2012). It has been estimated that during drives for unionization " 25 percent of employers fire at least one pro-union worker, 51 percent threaten to close a work site if the union prevails and, 91 percent force employees to attend one-on-one anti-union meetings with their supervisors" (Maisano, 2011, p. 4). Employers are allowed to appeal and delay a prounion vote. Simmons and Harding (2009), noting other anti-union strategies such as job exporting and an increased use of part-time workers, argue that government and corporations have worked together against organized labor by decreasing industry regulations relevant to wages, hours, and the right to organize.

One current issue is the preferred use by unions of card check, instead of a ballot, to gain recognition. Unions claim that with ballot voting, "companies intimidate workers" and employers "have far greater access and ability to persuade workers than the union has" (Greenhouse, 2012a). Congress has not approved a law which would 
give unions the right to insist on using card check, but regulations issued by the National Labor Relations Board (NLRB) do require companies to inform workers about their rights to organize through bulletin board posters and availability of union literature (Greenhouse, 2011a).

As noted earlier, the media are typically unfriendly to organized labor, often treating unions "as advocates of arcane work rules, protectors of inefficient public employees and obstacles to the economic growth our bold entrepreneurs would let loose if only they were free from labor regulations" (Dionne, 2011). Dionne argues that investors are presented in the media as heroes, while workers are the sideshow, whose activities, jobs, and lives are ignored and rarely covered, reflecting a "cool indifference to the heroism of those who go to work every day". It is important to note that, over the past decades, when the media have reported favorably and positively about unions, and when the government has played a neutral role rather than supporting employers, union membership has climbed (Loomis, 2011).

\section{Why Should Psychologists Care?}

Psychologists should be very interested in the on-going work of organized labor because of unions' historical and continued significant contributions to worker health and welfare. All the goals of traditional union organizing and activism are focused on contributing positively to the welfare of individuals and families In 2011, for example, the median take-home pay for union workers was $\$ 917$ a week compared with $\$ 717$ for non-union workers, a 28\% difference (Collins, 2011). But beyond wages and higher pay, it is the union movement in the U.S. that has won what most now take for granted: 
benefits, sick days and medical leave, weekends, maternity leave, overtime, worker's compensation benefits, child labor laws, employer based health coverage, retirement plans and pensions, vacations, and rules for safe working conditions and practices (cf. Mann, 2011).

It is organized labor's commitment to obtaining and maintaining both economic benefits and fair and decent workplaces that is the basis of its viability, strength, and significance. From the beginning, these achievements have benefited nonunion employees as well as union workers, and many of these benefits have been codified into federal or state law. In summing up the host of varied positive consequences of collective bargaining by unions in the U. S., Cobble (2007) includes: increasing the supply of good jobs at all levels of education; increasing political participation; and "ensuring that individuals have dignity and time for themselves, their families, their friends, and their communities" (p. 8).

An absolute priority of organized labor is to make the workplace as safe as possible (Bulger, 2001), and unions have saved lives and prevented serious injuries. In the coal industry, for example, one study found a decline of at least one-third in such statistics in mines that are unionized (cf. Meister, 2011). The major mine disasters in the past few decades all took place in nonunion mines. Prior to 1966 employers were not required to, and argued that they need not, discuss issues of worker health and safety with the union. This changed when the NLRB ruled that these were legitimate issues for collective bargaining. As noted by Kelloway (2004, p. 251), unions press for "three basic rights of workers: the right to know (about hazards in the workplace\}, the 
right to participate (in removing hazards and improving workplace safety), and right to refuse unsafe work."

Western and Rosenfeld (2011) argue that unions contribute to the "moral economy" by reinforcing the value of fairness and placing the value within an institutional framework. Zweig (2004) makes the point that unions are not just about money but about respect and fairness - securing an equitable share of what labor produces and providing "a decent life for the worker and his or her family" (p. 9). By advancing and protecting the rights of workers, unions are part of the larger movement for civil rights, and part of the progress made to reduce ethnic and gender inequities in the economy (Isaac \& Christiansen, 2002; Chang, 2003). One study (Drago, Colbeck, Hollenshead, \& Sullivan, 2008) found a positive effect of faculty unionization on family related organizational policies. Using faculties in English and Chemistry as respondents, the investigators found (in the over 500 colleges and universities that they surveyed) that the unions had promoted work-family policies that led to a decrease in the use of behaviors that minimize the appearance of family commitments in order to enhance career success. Such "bias avoidance" stategies were found to be significantly less likely in colleges with faculty unions.

Labor unions, as the active and legal voice of organized workers (Gordon, Jaurequi, \& Schnall, 2009), make significant contributions to the enhancement of union members' well-being. Direct benefits to individuals from union membership and participation include increased opportunities for companionship, unified action to achieve positive goals, social connectedness, a sense of community, trust, and ability to 
redress grievances (Mann, 2011; Pacek, 2009). Union membership provides the opportunity for control and power over some aspects of one's work life and important family life events, thus promoting self-esteem and psychological well-being and autonomy (Rosenberg, 2009). A sense of empowerment follows from the experience of having a clear group "voice" and from collective action (Isaac \& Christiansen, 2002; Sharp. 2011).

Radcliff (2005) calls attention, also, to the role unions play in enhancing members' communication, social, and problem-solving skills and in promoting more knowledgeable and active citizenship. Thus, for example, union members are more likely than non-members to vote in presidential and congressional elections, regardless of such individual characteristics as income, education, and occupation (Leighley \& Nagler, 2007). States with stronger unions have greater voter turnout. In the 2012 presidential election, organized labor played a crucial role (Greenhouse, 2012c; Metzger, 2012). Almost 20 percent of voters, nationally, came from union households and their votes were overwhelmingly for President Obama.

Fuller and Hester (2001, p. 1096), who surveyed members of a steelworkers' local in the southeast, found that union membership can satisfy socio-emotional needs "the need for approval, self-esteem, affiliation, and respect." These data are similar to those obtained from a sample of 17 industrialized democracies in which union members were found to express greater satisfaction with their lives (cf. Radcliff, 2005). Persons living in countries with greater levels of unionization showed more evidence of subjective well-being. 
There is a documented positive relationship between union membership and job satisfaction (Artz, 2010), and "job satisfaction is one of the most important determinants of overall life satisfaction" (Coshow \& Radcliff, 2009, p. 286). Job satisfaction is most likely to follow from job security, a good work environment, and from having a voice in the conditions of one's work. Unions encourage social support networks, connections, and a sense of solidarity, and our psychological literature provides empirical support for the conclusion that subjective well-being is positively related to social connectedness.

Coshow and Radcliff (2009) tested the hypothesis that union membership contributes to quality of life, using survey data from over 40,000 respondents in the 48 continental U. S. states who were polled annually from 1983 to 1999 . They found strong support, especially related to union membership density, and concluded that "the institution of the labor union is one with important felicitous social consequences" ( $p$. 294). Their data reinforce empirical findings about the negative mental and physical health consequences of job stressors from unfair workloads, low levels of on-the-job autonomy, and being under-rewarded (Dobson \& Schnall, 2009), the prevention of which are all union objectives.

A decline in unionized jobs has been correlated with growth in employment that is insecure, where layoffs can occur, and that does not provide fair pay, pensions or health benefits. Such "bad jobs" have been shown to negatively impact not just earnings, but also health and welfare (Raymo, et al., 2011). The retail and service jobs available to young people, where $68 \%$ of those between the ages of 16 and 24 are employed, and where unions are rare, are particularly characterized by high stress from repetitive 
tasks, uncertain hours and scheduling, few benefits, limited learning opportunities, and extremely high turnover (Tannock, 2004).

\section{Inclusion and Diversity}

In expanding outreach to membership, union leadership has become more and more welcoming to women, immigrants and people of color (Levi, 2001). Related to this effort is a clear and explicit focus on issues of discrimination and family life. A new bargaining concern, beyond livable wages, safety, health insurance, and retirement benefits, is having good supports for families such as flexibility in schedules, eldercare services, quality child and after-school care, paid family leave, and part-time work with benefits (Firestein \& Dones, 2007).

In 2005 , women were $43 \%$ of all workers covered by union contracts, with almost 7 million women members, making "organized labor...the largest women's movement in the country" (Cobble, 2007,p. 6). Unionized women earn an average of $31 \%$ more than women who are not in unions - with education, training, and education controlled (Bronfenbrenner, 2005). In 2004, union women on average earned $\$ 19.18$ per hour compared with $\$ 15.05$ an hour for women not in unions. In addition, as a result of the active pursuit of family issues, unionized women are much more likely to have such benefits as health insurance, paid time off, pensions, job protection for pregnant workers, family leave, and job flexibility (Milkman, 2007).

Union organizing victories have been greatest since the 1980s in work sectors with high percntages of women, particularly high percentages of women of color. These include the public sector, health care, home care, hotels, food services, light 
manufacturing, support staff in schools, and graduate students and adjunct faculty in universities (Bronfenbrenner, 2005; Milkman, 2007). One of the strongest voices in the contemporary union movement is that of National Nurses United, part of the Service Employees International Union (SEIC) (Sharp. 2011).

As noted by Cranford (2007, p. 410), "unions may become sites where women are able to renegotiate gender inequalities in significant ways." Thus, for example, Cranford found in a study of women janitors in union leadership positions that they were experiencing both personal and political transformations, empowerment, increased confidence to assert their views and to challenge the view that unions are the domain of men. Two of the top three leadership positions in the AFL-CIO are now held by women, and several national unions have women presidents (Mann, 2011). In addition to pressing for gender pay equity, such benefits as child and elder care have become bargaining priorities. Unions are also concerned with eliminating sexual harassment in the workplace, and some have put clear procedures in place to protect women and assist them in reporting abuses and discrimination (Bulger, 2001).

The CIO was an early force in working for civil rights and ethnic equality, pressing for integrated workplaces, integrated unions, and federal anti-discrimination legislation. During the famous sanitation workers strike in Memphis in 1968, supported by Dr.Martin Luther King, workers carried signs reading "I Am A Man” (Isaac \& Christiansen, 2002). African American workers now make up a disproportionately large portion of public sector workers and 15 to 17 percent of Black workers are members of unions - the largest proportion of any ethnic group (Rosenberg, 2009). As noted by King (2011, p. 
2), "Historically, unions have been crucial gateways for black workers to earn higher wages and break into the middle class." Unionized Black workers earn 35\% more and unionized Latino/a workers earn $51 \%$ more than their counterparts who are not in unions. It is thus not surprising to find that non-Whites in the U.S. express more prounion sentiments than Whites and "see the labor movement as an essential institution through which they can address their economic, social and political issues" (Chang, 2003, p. 192). There is a current focus on training Latino/a workers, 2.1 million of whom are unionized, and in supporting amnesty and citizenship for undocumented immigrants (Mann, 2011). May Day, the international worker's holiday, has become, in the U.S., an occasion for immigrant communities to express solidarity and voice their unique concerns (Johnston, 2012).

Some unions have worked to lessen discrimination against sexual minorities (Cobble, 2007) and, since 1997, the AFL-CIO has recognized its LGBT members as a formal constituency group. Pride at Work, the officially recognized group, had 16 chapters by 2005. Thus, with regard to its efforts to combat discrimination against sexual minorities, the U.S. labor movement "has shifted from being part of the problem to being part of the solution" (Hunt \& Boris, 2007, p. 98).

There is a renewed focus on low-wage workers, part-timers, and temporary workers, who are often "invisible" (Hertz, 2010; Simmons \& Harding, 2009), and a growing interest in attracting immigrant and young workers to unions. Such workers are found in domestic service, not subject to most labor and safety laws. They are also found in McJobs - low-wage and low-skill service, hotel and retail jobs - that are 
generally regarded as "dead-end." Such a label tends to devalue the work and discourages efforts to improve conditions. It is also a source of feelings of shame (Nall, 2012). A study of young workers in supermarket unions found that the union had succeeded in raising wages and increasing benefits and providing protection from mistreatment and from being fired (Tannock, 2004). Average turnover in such jobs is often more than $100 \%$, since these jobs are highly stressful and repetitive, with great uncertainty in hours and schedules.

According to the International Labor Organization, the U.S. has the largest share of low-paid jobs among all industrialized countries. The lowest paid are in limitedservice restaurants like McDonalds that employ more than two million workers; and 57 percent of personal home care aides, the fastest growing occupation, live in poverty (cf. Porter, 2012). Unions, collaborating with social justice and civil rights groups, are sponsoring actions aimed at raising wages and improving conditions for such workers. Illustrative of this effort is a multi-restaurant strike by fast-food workers in New York City (The Fast Food Campaign), whose median pay is $\$ 9$ an hour $(\$ 18,500$ a year for a fulltime worker) (Greenhouse, 2012d). Another union-supported group, the National Domestic Workers Alliance, has reported the results of a first-ever national survey of over 2,000 nannies, caregivers, and housecleaners in urban areas (Burnham \& Theodore, 2012). Using a participatory methodology, the investigators documented domestic workers' "vulnerability to exploitation and abuse... deeply rooted in historical, social and economic trends" (p. ix). 
Thus, unions are continuing their historical efforts to "improve the lives of lowwage workers and...reduce inequality" (Greenhouse, 2008, p. 242) - adding inequality stemming from age and lesser skills to that of ethnicity and gender.

\section{Advancing Psychology's Research Agenda}

Related to our neglect of scholarship on social class are unrecognized implicit assumptions about working class characteristics that can be found in our literature (see Lott, 2010, 2012; Lott \& Bullock, 2007). Rose (2004) has written movingly about judgments typically made in the media and elsewhere, by those in the middle-class, about the intelligence of people who labor in service work or in the manufacturing of products - work often described as "mindless" and considered to be "neck down" rather than "neck up." He notes that we tend to judge a person's intelligence by the work she or he does, and warns that we undermine our ability to reliably understand a social class culture if we begin by assuming persons in it are not as smart as we are. He presents us with a statement psychologists could well utilize as a testable hypothesis for careful study: "most working men and women try to find meaning in what they do through the activity of the work itself or through what their wages make possible outside of the workplace" (p. 197). How acuurate is this for workers in diverse workplaces - including "excluded workers", those who are outside the traditional protections offered to workers by practice or law (T. Williams, 2012)?

Another testable hypothesis, suggested by Richard Trumka (cf.

Richardson, 2011), President of the AFL-CIO, is that most people in the U.S. are 
largely ignorant of labor union history and leaders. How do demographic groups differ with respect to such a characterization? Is knowledge of corporations greater, lesser, or the same as knowledge about unions? What variables correlate with beliefs and attitudes about collective bargaining? Are minorities of color and people who have experienced negative economic events more prounion than others (Chang, 2003)? What psychological characteristics distinguish the 52 percent of Americans found in a recent Gallup poll to approve of unions (cf. Greenhouse, 2011b). Dionne (2011) has written of "our cool indifference to the heroism of those who go to work every day". How common is such indifference? What are the antecedents and correlates of such feelings? Our social psychological literature contains much that can help us to understand the phenomenon of scapegoating. This would seem to be a highly relevant construct in an investigation of the current targeting of unions (e.g., teachers' unions) as being to blame for the hard economic times experienced by cities and states. Within our discipline there is a considerable amount of research on how family life is influenced by employment and a variety of job-related factors, and empirical attention has been paid to the importance of work experiences for individuals and families. As noted earlier, APA's Public Interest Directorate held a congressional briefing on "The Power of Work" that dealt with the impact of joblessness and the positive effects of job satisfaction on relationships and wellbeing (APA, 2011). Yet, as Zickar (2004) notes, psychology remains indifferent to research relevant to labor unions and their wide-ranging positive contributions 
to persons, communities, and nations. There are exceptions, such as a paper on the impact of work on mental health which links anti-union developments to increased work-place stressors, decreased autonomy, under-rewards, and distress (Dobson \& Schnall, 2009).

Should psychologists be concerned with the fact that nearly half of workers in the U.S. get no paid sick days (Greenhouse, 2006)? Can we ignore the consequences of this state of affairs for family well-being and ignore the research data documenting that children get well sooner if their parents can take time off from work to care from them? Cities and states have begun to legislate on this issue, with San Francisco, Washington, DC, Seattle, and Connecticut now guaranteeing paid sick days for workers (Ness, 2012).

APA's most recent mission statement (APA, nd), cited at the beginning of this paper, states clearly that we strive to contribute, and to apply, "psychological knowledge to benefit society and improve people's lives." Our goals include achievement of "social justice, diversity, and inclusion". Surely, then, it is time for us to widen our vision and accept social class as a vital feature of personal and community identification and life. Doing so will encourage recognition of the significance of such class based institutions as organized labor, and attention to their efforts to benefit society and improve lives.

References

Adams, G. A., \& Rau, B. L. (2011). Putting off tomorrow to do what you want today. American Psychologist, 66, 180-192. 
American Psychological Association (nd). APA mission statement. Retrieved from http://www.apa.org/about/index.aspx

American Psychological Association. (2011, October 19). APA briefing on unemployment makes an impact on Capital Hill. Retrieved from http://www.apa.pi

Artz, B. (2010). The impact of union experience on job satisfaction. Industrial Relations: A Journal of Economy \& Society, 49, 387-405.

Bodnar, J. (2003). Blue-collar Hollywood: Liberalism, democracy, and working people in American film. Baltimore: Johns Hopkins University Press.

Bread and Roses Centennial, 1912-2012. Retreived from http://www.breadandrosescentennial.org

Brennan, B. (2004). The emergence of class consciousness in the American Newspaper Guild. In Heider, D. (Ed.) Class and news (pp. 233-247). London: Rowan \& Littlefield.

Bronfenbrenner, K. (2005). Organizing women: The nature and process of unionorganizing efforts among U.S. women workers since the mid-1990s. Work and Occupations, 32, 441-463.

Bulger. C. (2001). Union resources and union tolerance as moderators of relationships with sexual harassment. Sex Roles, 45, 723-741.

Burnham, L., \& Theodore, N, (2012). Home economics: The invisible and unregulated world of domestic work. New York: National Domestic Workers Alliance. Center for Urban and Economic Development, University of Illinois at Chicago. 
Chang, T. F. H. (2003). A structural model of race, gender, class, and attitudes toward labor unions. The Social Science Journal, 40, 189-200.

Chen, M. (2010, November). The truth about civil servants. In These Times, 34(11), pp. 10-11.

Chen, M. (2012, October 15). \$950,000 win for NYC worker invigorates supply-chainjustice movement. Truth Out. Retrieved from http://truth-out.org/news/item/12124

Cobble, D. S. (Ed.) (2007). Introduction. The sex of class: Women transforming American labor (pp. 1-12). Ithaca, NY: Cornell University Press.

Collins, M. (2011, May 17). Strong unions: The worst nightmare for the financial elite. Truthout. Retrieved from http://truth-out.org/print/2210

Cooke, S. (2011, July 28). How to save the US labor movement. Truth Out. Retrieved from http://truth-out.org/print/4176

Coshow, S. M., \& Radcliff, B, (2009). Labor organization and the quality of life in the American states. In A. K. Dutt \& B. Radcliff (Eds.) Happiness, economics and politics: Toward a multidisiplinary approach (pp. 285-300). UK: Edward Elgar Cheltanham.

Cranford, C. J. (2007). "It's time to leave Machismo behind!" Challenging gender inequality in an immigrant union. Gender \& Society, 21, 409-438.

Crosby, F. J., Stockdale, M. S., \& Ropp, S. A. (Eds.) (2007). Sex discrimination in the workplace: multidisciplinary perspectives. UK: Blackwell.

Diamond, M. (2011, December 1). After locking out 1,300 union workers, food company 
CEO compares them to cancerous tumor. Nation of Change. Retrieved from http://www.nationofchange.org/print/3854

Dingfellder, S. F. (2011, September). An uncertain future for America's work force. Monitor on Psychology, pp. 42-46.

Dionne, E. J. Jr. (2011, September 5). The last labor day. Truth Out. Retrieved from http://truth-out.org/last-labor-day/1315243815

Dobson, M., \& Schnall, P. L. (2009). From stress to distress: The impact of work on mental health. In P.L. Schnall, M. Dobson, \& E. Rosskam (Eds.) Unhealthy work: Causes, consequences, cures (pp. 113-132). Amityville, NY: Baywood.

Drago, R., Colbeck, C., Hollenshead, C., Sullivan, B. (2008). Work-family policies and the avoidance of bias against care-giving. In A. Marcus-Newhall, D. F. Halpern \& Tan, S. J. (Eds.) The changing realities of work and family (pp. 43-66). UK:Blackwell.

Dutt, A.K., \& Radcliff, B. (Eds.) (2009). Introduction. Happiness, economics and politics: Toward a multi-disciplinary approach (pp. 1-21). Cheltenham, UK: Edward Elgar.

Feeney, L. (2012, July 10). Inequality rises as union numbers decline. TruthOut. Retrieved from http:/truth-out.org/news/item/10246-inequality-rises-as-unionnumbers

Finison.L. J. (1986). The psychological insurgency: 1936-1945. Journal of Social Issues, 42, 21-33.

Firestein, N., \& Dones, N. (2007). Unions fight for work and family policies - Not for 
women only. In D. S. Cobble (Ed.) The sex of class: Women transforming American labor (pp. 140-154). Ithaca, NY: Cornell University Press.

Flanders, L. (2012, September 3). Help workers connect the dots to this larger system of oppression. TruthOut. Retrieved from http://truth-out.org/opinion/item/11260hellp-workers-connect

Fuller, J. B., \& Hester, K. (2001). A closer look at the relationship between justice perceptions and union participation. Journal of Applied Psychology, 86, 10961105.

Gordon, D. R., Jauregui, M., \& Schnall, P. L. (2009). Stakeholder perspectives on work and stress: Seeking common ground. In P.L. Schnall, M. Dobson, \& E. Rosskam (Eds.) Unhealthy work: Causes, consequences, cures (pp. 173-192). Amityville, NY: Baywood.

Greenberg, J. (2011). Orgaizational justice: The dynamics of fairness in the workplace. In S. Zedeck (Ed.) APA handbook of industrial and organizational psychology Vol. 3. (pp. 271-327). Washington, DC:American Psychological Association.

Greenhouse, S. (2006, December 5). With the Democratic congress, groups gear up for fight over paid sick days. The New York Times. Retrieved from http://www.nytimes.com/2006/12/05/washington/05labor.html

Greenhouse, S. (2008). The big squeeze: Tough times for the American worker. NY: Alfred A.Knopf.

Greenhouse, S. (2011a, August 25). New rules seen as aid to efforts to unionize. The 
New York Times. Retrieved from

http://www.nytimes.com/2011/08/26/business/labor-agenc

Greenhouse,, S. (2011b, September 2). A challenge for unions in public opinion. The New York Times. Retrieved from http://economix.blogs.nytimes.com/2011/09/02challenge-for-unions

Greenhouse, S. (2012a, August 30). G.O.P. platform seeks to weaken powers of unions. The New York Times. Retrieved from http://thecaucus.blogs.nytimes.com/2012/08/30/g-o-p platform-seeks

Greenhouse, S. (2012b, September 10). In standoff, latest sign of unions under siege. The New York Times. Retrieved from http://www.nytimes.com/2012/09/11/education/in-chicago-teachers

Greenhouse, S. (2012c, November 12). Labor leaders have Obama's back and ready to help. The New York Times. Retrieved from http://www.nytimes.com/2012/11/13/us/politics/unions-offer

Greenhouse, S. (2012d, November 28). The drive to unionize, fast food workers walk off the job. The New York Times. Retrieved from http://www.nytimes.com/2012/11/29/nyregion/desire-to-unionize

Griffin, M. A., \& Clarke, S. (2011). Stress and well-being at work. In S. Zedeck (Ed.) APA handbook of industrial and organizational psychology. Vol 3. (pp. 359-397) Washington, DC:American Psycological Association

Hammer, L.B., \& Zimmerman, K. L. (2011). Quality of work life. In S. Zedeck (Ed.) APA handbook of industrial and organizational psychology. Vol 3. (pp. 399-431) 
Washington, DC:American Psychological Association.

Heider, D. (Ed.) (2004). Introduction. Class and news (pp. 1-5). London: Rowan \& Littlefield.

Hertz, R. (2010). Economic crisis and new social realities: Bait and switch and the American dream - Presidential address 2010. Sociological Forum, 25, 643-654.

Hunt, G., \& Boris, M. B. (2007). The lesbian, gay, and transgender challenge to American labor. In D. S. Cobble (Ed.) The sex of class: Women transforming American labor. Ithaca, NY: Cornell University Press.

Isaac, L., \& Christiansen, L. (2002). How the civil rights movement revitalized labor militancy. American Sociological Review, 67, 722-746.

Johnston, A. (2012, April/May). All out for May Day. The Boston Occupier. Retrieved from bostonoccupier.com

Kahlenberg, R. D., \& Marvit, M. Z. (2012, February 29). A civil right to unionize. The New York Times. Retrieved from http://www.nytimes.com/2012/03/01/opinion/acivil-right-to-unionize

Kelloway, E. K. (2004). Labor unions and occupational safety: Conflict and cooperation. In J. Barling \& M. R. Frone (Eds.) The psychology of workplace safety (pp. 249264). Washington, DC: American Psychological Association.

King, J. (2011, February 2). Why Black union workers matter in this year's super bowl showdown. TruthOut. Retreived from http://truth-out.org/print/12219

Leighley, J.E, \& Nagler, J. (2007). Unions, voter turnout and class bias in the U.S. electorate, 1964-2004. The Journal of Politics, 69, 430-441. 
Levi, M. (2001). Capitalizing on labor's capital. In S. Saegert, J. P. Thompson, \& M. R. Warren (Eds.) Social capital and poor communities (pp. 246-266). New York: Russell Sage Foundation.

Lichtenstein, N. (2012, fall). Can the unions survive? Can the Left have a voice? Democratic Left, Vol XL (2), 3-4.

Loomis, E. (2011). Eight union victories progressives should be watching - and learning from. Retrieved from http://www.truth-out.org/print/5031

Lott, B. (2010). Multiculturalism and diversity: A social psychological perspective. UK: Wiley.

Lott, B. (2012). The social psychology of class and classism. American Psycholgist, $67,650-658$.

Lott, B. \& Bullock, H. E. (Eds.) (2001). Listening to the voices of poor women [Special Issue]. Journal of Social Issues, 57 (2).

Lott, B. \& Bullock, H. E. (2007). Psychology and economic injustice:

Personal, professional, and political intersections. Washington, D.C.: APA.

Luce, S. (2005). Lessons from living wage campaigns. Work and Occupations, 32, 423-440.

Maisano, C. (2011, fall). The death and life of the US labor movement. Democratic Left, pp. 3-5.

Mann, E. (2011, May 23). Ten reasons protecting unions is a life-and-death issue. Truthout. Retrieved from http://www.truth-out.org/print/2408 Martin, C. R. (2004). Framed! Labor and the corporate media. Ithaca: Cornell 
University Press.

Meister, D. (2011, June 14). Unions save lives. Truthout. Retrieved from http://www.truth-out.org/print/2962

Metzgar, J. (2012, November 12). Union vote declining but still crucial. Working Class Studies. Retrieved from http://www.classism.org/union-vote-declining-crucial Milkman, R. (2007). Two worlds of unionism: Women and the new labor movement. In D. S. Cobble (Ed.) . The sex of class: Women transforming American labor (pp. 63-80). Ithaca, NY: Cornell University Press.

Moberg, D. (2011, July). Unions work to turn the tide. In These Times, 35 (7), pp. 2225.

Nall, J. (2012, October 26). Lies of plutocracy:Exploding five myths that dehumanize the poor. Truthout. Retrieved from http://tryth-out.org/news/item/12264-lies-ofplutocracy

Ness, D.L. (2012). This Labor Day, Seattle working families have new workplace standard to celebrate as historic paid sick days law takes effect. National Partnership for Women and Families. Retrieved from http://national/partnersip.org/site/News2?

Noguera, P., \& Fine, M. (2011, May 6). Public school teachers and their unions are under attack - Here's how. AlterNet. Retrieved from http://www.alternet.org/module/printversion/150727

Pacek, A.C. (2009). Politics and happiness: An empirical ledger. In A. K. Dutt \& B. 
Radcliff (Eds.) Happiness, economics and politics: Toward a multidisiplinary approach (pp. 231-255). UK: Edward Elgar Cheltanham.

Porter, E. (2012, December 4). Unionizing the bottom of the payscale. The New York Times. Retrieved from http://www.nytimes.com/2012/12/05/business/unionizingat-the

Psychologists for Social Responsibility (2011). Psychological health and well-being: An exploration and action agenda. Retrieved from http://www.psys.org/about/programs/wellbeing/psyvlchological-health.php

Radcliff, B. (2005). Class organization and subjective well-being: A cross-national analysis. Social Forces, 84, 513-530.

Raymo, J._M., Warren, J. R., Sweeney,M. M., Hauser, R.M., \& Ho, J-H. (2011). Precarious employment, bad jobs, labor unions, and early retirement. The Journals of Gerontology: Series B: Psychlogical Science and Social Sciences, 66, 249-259.

Remes, J. (2012). May Day's radical history, What Occupy is fighting for this May $1^{\text {st }}$. AlterNet. Retrieved from http://www.alternet.org/story/155182/may-day

Richardson, J. H. (2011). Richard Trumka, American. Esquire. Retrieved from http://www.esquire.com.features/americans-2011/richard-trumka-1211

Rose, M. (2004). The mind at work: Valuing the intelligence of the American worker. NY:Viking.

Rosenberg, J. (2009). Organized labor's contribution to the human services: Lessons 
from the past and strategies for the future. Journal of Workplace Behavioral Health, 24, 113-124.

Rosenthal, A. (2012). The war on organized labor. The New York Times. Retrieved from http://loyalopposition.blogs.nytimes.com/2012/02/02/the-war-on

Rozensky, R. H., Johnson. N. G., Goodheart, C., \& Hammond, W. R. (Eds.).(2004). Psychology builds a healthy world. Washington, DC:American Psychological Association.

Scott, A. O. (2012, September 27). A political football in the classroom. The New York Times. Retrieved from http://movies.nytimes.com/2012/09/28/movies/wont-backdown

Sharp, K. (2011, November 19). Redefining the union boss. The New York Times. Retrieved from http://www.nytimes.com/2011/11/20/business/women are becoming

Shultz,, K. S., \& Wang, M. (2011). Psychological perspectives on the changing nature of retirement. American Psychologist, 66, 170-179.

Simmons, L., \& Harding, S. (2009). Community-labor coalitions for progressive change. Journal of Workplace Behavioral Health, 24, 99-112.

Tannock, S. (2004). Youth and unions in North America's service society. In A-N., Perret-Clermont, C.Pontecorvo, L. B. Resnick, T. Zittoun, \& B.Burge (Eds.) Joining society: Social interaction in adolescence and youth (pp. 308-317). NY: Cambridge University Press.

Vinchur, A.J., \& Koppes, L. L. (2011). A historical survey of research and practice in 
industrial and organizational psychology. In S. Zedeck (Ed.) APA handbook of industrial and organizational psychology. Vol. 1 (pp. 3-36). Washington, DC:American Psycological Association.

Wang, M., Henkins, K., \& van Solenge, H. (2011). Retirement adjustment: A review of theoretical an empirical advancements. American Psychologist, 66, 204-214.

Western, B, \& Rosenfeld, J. (2011). Unions, norms, and the rise in American wage inequality. American Sociological Review,

Williams. J. C. (2012). The class culture gap. In S. T. Fiske \& H. R. Markus (Eds.) Facing social class (pp. 39-57). NY: Russell Sage.

Williams, T. (2012, September 5). What will excluded workers celebrate next Labor Day? Institute for Policy Studies. Retrieved from http://www.ips-dc.org/blog/what -will -excluded -workers -celebrate

Zandy, J. (2004). Hands: Physical labor, class, and cultural work. New Brunswick, NJ: Rutgers University Press.

Zedeck, S. (Ed.) (2011). APA handbook of industrial and organizational psychology (3 volumes). Washington, DC: American Psychological Association.

Zickar, M. J. (2003). Remembering Arthur Kornhauser: Industrial psychology' advocate for worker well-being. Journal of Applied Psychology, 88, 363-369.

Zickar, M. J. (2004). An analysis of industrial-organizational psychology's indifference to labor unions in the United States. Human Relations, 57, 145-167.

Zweig, M. (2004). Introduction. In M. Zweig (Ed.) What's class got to do with it? (pp. 1 21) Ithaca, N.Y.:Cornell University Press. 